\title{
Analysis Juridical Public Participation Formation of Regional Regulation No. 3 of 2017 on The Implementation of The Business Entertainment In Wonosobo Regency
}

\author{
Amin Syarifudin ${ }^{1}$ and Rakhmat Bowo Suharto ${ }^{2}$
}

Abstract. To set the order and comfort in the Wonosobo regency and Goverment Wonosobo regency make Region Regulation No. 3 of 2017 on the Implementation of Enterprise Entertainment in Wonosobo. This is associated with the rise of karaoke business premises in Wonosobo. But after the regulation passes reap a lot of conflict in the community. This makes the writer interested in making. Juridical Analysis of Public Participation in Formation of Regional Regulation Number. 3 of 2017 on the Implementation of Enterprise Entertainment in Wonosobo,

Method of approach used in this study is a sociological juridical methods, using the principles and legal principles in reviewing, view, and analyze problems.

According to Act No. 12 of 2011 Establishment Regulation Legislation. Article 96 "The public has the right to give feedback in oral and / or written in question can be done through public hearings, working visits, socialization and / or, seminars, workshops and / or discussion.

In the establishment of the Regional Regulation No. 3 Of 2017 on the Implementation of Enterprise Entertainment in Wonosobo regency public participation, not maximum.

Constraints in the face is the lack of public interest in participating, goverment is valued less the aspirations of the people should be overcome by it, provide an understanding of the importance of public participation in Formation of Regional Regulation 3 Of 2017 about the entertainment business in Wonosobo, maximizing the dissemination of the regulations and the third accommodate all the aspirations of the people

Keywords: Public Participation; Local Regulation; Entertainment.

\section{Introduction}

Community participation is a form of democracy. As we know that democracy is run in Indonesia is a democracy. The member representation of the parliament is elected in the commonly. DPRD as legislative authority to formulate local regulations. As a stakeholder, the public has the right to provide input in writing or verbally in the framework of the preparation or discussion of the draft regulation of the manner of local areas in accordance with the order of Parliament (Act No. 12 of 2011).

\footnotetext{
${ }^{1}$ Student of Master of Law, Universitas Islam Sultan Agung Semarang and FSH LKBH UNSIQ email: aminsyarifudin128@gmail.com

${ }^{2}$ Faculty of Law Universitas Islam Sultan Agung
} 
Establishment of regulations legislation, never separated from the third runway Legislation drafting of regulations, namely: philosophical, juridical, and political. If the political foundation which dominates the formation of local regulations, so the representatives often do not heed the interests represented (folk), but rather political motoring interests (supporting political parties) or even the interests of the public. Participation (stakeholders) in the establishment of local regulations is important. ${ }^{3}$

Based on Act No. 12 Of 2011 on the Establishment Regulation Legislation Article 96 of the Public Participation, explained that:

- Society has the right to provide input verbal and / or written in the formation of legislation-Invite.

- Put orally and / or in writing referred to in paragraph (1) can be done through: a. Public hearing, b. Working Visit, c. Socialization; and / or, d. Seminars, workshops, and / or discussion. ${ }^{4}$

To facilitate the public to provide input verbally and / or writing referred to in paragraph (1), each draft Regulation Legislation should be easily accessible by the public. "To establish local regulations that can meet the aspirations of the public wants must be balanced with namely community involvement; involvement in the discussion of local regulations. ${ }^{5}$

Wonosobo regency is one of the growing district in Central Java province. Developments undertaken aim to promote the welfare of the community the Wonosobo regency both in terms of social, economic, educational, health, and others. ${ }^{6}$ In implementing regional autonomy, local governments tried to regulate Wonosobo regency alone one with the issue of legal products that aim to ensure order and security in the region associated with the rise of Wonosobo in Wonosobo regency entertainment businesses in the form of Regional Regulation Number. 3 Of 2017 About the organization of Entertainment Businesses in Wonosobo regency.

The legal basis for the Government of Wonosobo issued Local Regulation Nomor.3 Of 2017 On Implementation of Entertainment Businesses in Wonosobo regency. Among them:

- Article 18 paragraph (6) of the Constitution of the Republic of Indonesia of 1945

- Act No. 12 Of 2011 on the Establishment of Legislation

- Act No. 23 of 2014 on Regional Government. ${ }^{7}$

Entertainment businesses contained in Article 1 (9) Regional Regulation Number. 3 of 2017 is any commercial venture whose scope of activities includes the type of shows,

\footnotetext{
${ }^{3}$ Satjipto Raharjo. 1998. "Mencari Model Ideal Penyusunan UU Yang Demokrasi (Kajian Sosiologis)". Papers presented at a national seminar looking for the ideal model of democratic rule of law drafting and legal sociology association congress Indonesia, Semarang 15-16 April 1998

${ }^{4}$ Act No. 12 of 2011 on the Establishment Regulation Legislation

${ }^{5}$ Praptanugraha, 2008, Partisipasi Masyarakat Dalam Pembentukan Peraturan Daerah, Journal of Law No. 3 VOL. July 15th, 2008: 459-473, Faculty of Law, Islamic University of Indonesia, p. 470

${ }^{6}$ Nurdin H. kistanto,dkk, Sejarah Wonosobo, Pemerintah Daerah Kabupaten Wonosbo 2008), Wonosobo

${ }^{7}$ Regional Regulation Number. 3 of 2017 on the Implementation of Enterprise Entertainment in Wonosobo
} 
games and or the crowds with whatever name and form watched or enjoyed by any person by paying. Eventhe type of entertainment that is set in the regulations is the Arena game, Karaoke, Home Massage, Nightclubs, discos, art performances, performances of music / dance, circus, acrobatics, magic, Performing Animal Arena. ${ }^{8}$

\section{Research Methods}

The approach used in this study is a method socio-juridical, that in addition to using the principles and legal principles in reviewing, view, and analyze the problems, this study also review how its implementation. ${ }^{9}$ This study examines the public participation in the establishment of regional regulations (the study of public participation in the process of formation of local regulations No. 3 Of 2017 About Entertainment Enterprises in Wonosobo regency.

\section{Results and Discussion}

\subsection{Public Participation in Formation of Regional Regulation No. 3 Of 2017 About the Entertainment Business in Wonosobo}

The interview with Tofek the chairman of the committee special Ranperda No. 3 Of 2017 on entertainment business, he said; As the seriousness of Wonosobo Regency in planning for the draft regional regulation No. 3 of 2017 on entertainment business in the process takes as long as two years, beginning in 2015 and with a very careful and do some certain steps that include conduct hearings to absorb the aspirations society carried on around the beginning of 2015 in the main house of Parliament Wonosobo which was attended by representatives of organizations working, Nahdlatul Ulama, Muhammadiyah, religious leaders, Christian and Hindu, it is meant that after regulated no protests from the community because the community in engage as the principle of openness. According contained in principle the establishment of the legislation of Article 5 paragraph g of "openness" of Act No. 12 Of 2011 on the Establishment Regulation Legislation. ${ }^{10}$

Ranperda (draft local regulations) initiative Wonosobo regency legislature about the entertainment business are discussed among academics and stakeholders. Ranperda Wonosobo regency on the entertainment business this time initiated by the Council of Wonosobo, an initiation that is admirable considering the rampant of Wonosobo entertainment business demands serious attention from the government. As a rule issued in the area, it would be better, effective and benefits as well as being the fulfillment of any conditions and problems that occur in Wonosobo regency.

\footnotetext{
${ }^{8}$ Ibid.

${ }^{9}$ Roni Hanitijo Soemitro, 1990, Metodologi Penelitian Hukum dan Jurimeti, Ghalia Indonesia, Jakarta, , p. 33.

${ }^{10}$ Interview with Tofek legislators Wonosobo regency / Chairman of the Special Committee of Perda No.3 Year 2017 Wonosobo February 15, 2019
} 
The process of formation of local laws in the Wonosobo regency which described by Toufek are as follows: ${ }^{11}$

\section{- Planning and arranging}

The initial step is the planning and identification of issues and problems. What is planning. Such as any existing problems and how the things about these issues. After identifying issues and problems then do a baseline legal identification or legal basis, as well. ${ }^{12}$

In this case, issues and problems raised was regarding business entertainment in Wonosobo regency.

\section{- Discussion}

After preparation of the Academic and Ranperda completed, the next activity is a discussion for comments and comparisons from the standpoint of the public and stakeholders. This can be done by Parliament Wonosobo, with a working meeting, public hearing (public consultation), or dissemination by inviting relevant SKPD, community representatives, non-governmental organizations related to the organization of the entertainment business raised in regulation. ${ }^{13}$

\section{- Ratification / promulgation}

in the Ranperda discussion in the final meeting in Parliament have been completed and approved by the legislature, Ranperda will be sent by the chairperson of Parliament to the Head of Region through the Regional Secretariat in this regard the Legal department for approval. Numbering of the regulation made by the Law Department. Head of Legal Division will perform authentication. Regional Head certify by signing the new law to be passed by the Regional Secretary. Even Legal Department is responsible for the duplication, distribution and documentation of these rules. $^{14}$

\section{- Socialization}

In order to have legal force and can bind society, legislation that has been approved by the Regional Head should be enacted in region. Regional Regulation which legitimated by Gazette shall promulgate legislation that has been enacted in the Regional Gazette so that all the people in the local area and other interested parties informed.

In line with this add a Miswanto as a member of the Special Committee, legislators Wonosobo regency in aspiration to visit places of entertainment Karaoke for aspirations of entrepreneurs and visitors karaoke establishments. From these results, all parties agreed with local regulations governing any entertainment establishments

\footnotetext{
${ }^{11}$ Interview with Tofek the Chairman of the Special Committee of Parliament Member Perda No.3 of 2017 Wonosobo February 15, 2019

${ }^{12}$ Interview withTofek the Chairman of the Special Committee of Parliament Member Perda No.3 of 2017 Wonosobo February 15, 2019

${ }^{13}$ Https: //Id.Scribd/..../Pembuatan -PERDA-Proposed-Regional Initiative

${ }^{14}$ lbid.
} 
and drafted a planning regulation accordance with the aspirations of people. According to Miswanto these regulations are in accordance with the procedural namely the involvement of the community or the appropriate public participation in the Standing Orders of the House of Representatives of the Republic Indonesia is determined that: ${ }^{15}$ Results of interviews with Sugeng Susilo that reason Wonosobo regency society to participate in the formation of local regulations is because the people themselves who will implement local regulations, while the government only oversees implementation. ${ }^{16}$ Added by Misron, that the reason for the public to participate in the formation of local regulations in Wonosobo, namely:

- Their sense of Wonosobo; and

- Local regulations are created / arranged in accordance with the public interest.

From the view of the members of the community the Wonosobo regency, the reason the public to participate in the formation of No.3 of 2017 on Regional regulations concerning the entertainment business in Wonosobo, among others: ${ }^{17}$

- Local regulations are created for the benefit of the community would be more appropriate and targeted;

- Society is a government stakeholders, and the public is the direct object of local legislation itself;

- In order for local regulations that could be made more leverage.

There are several techniques that can be adopted by the government in order to establish participatory local regulations. Brenda Dubois and Karla Kongsrud Miley, revealed some community empowerment techniques commonly used by the group of non-governmental organizations (NGO = Non Government Organization). Among them there is a way to create an empowered society (political) that can be adopted by the government in an effort to realize good governance that is transparent, participatory, aksesabel, and accountable. ${ }^{18}$ Even of Branch Executive Nahdlatul Ulama and Muhammadiyah agree and support the local regulations entertainment business operation in Wonosobo regency. ${ }^{19}$

Meanwhile, according to Chairman of the Karaoke Association (Aspara) Wonosobo, Tia Viandari said that it has not in involve the establishment of Regulation No. 32017 regarding business entertainment only once invited the first time discussed the plan further sodium absorption ratio has been involved again. He said he felt disadvantaged because there are rules that limit their business rules, according to his close call Vivi comprehensive entertainment is not only a place of entertainment karaoke only in the

\footnotetext{
15 Interview With Miswanto Member of Parliament Members of the Special Committee Perda No.3 of 2017 Wonosobo,, February 15, 2018

${ }^{16}$ Interview with Sugeng Susilo, Community Wonosobo On the date February 16, 2019.

${ }^{17}$ Interview with Misron as members of the community the Wonosobo district February 16, 2019

${ }^{18}$ Drafting regulations on access Repository.Unhas.ac.id/..Buku\%20Cara\%20praktis\%20 on March 11, 2019

${ }^{19}$ Interview with Mr. Arifin chairman of the board of the Branch Nahdotul Ulama kab. Wonosobo
} 
entertainment business regulations are very broad sense. ${ }^{20}$ The same thing was also conveyed by Nurhadi as a member of the community the Wonosobo regency whose house very close to the Karaoke entertainment business Tanjung himself had never been involved in the formation of these local regulations.

\subsection{Obstacles and Solutions of Public Participation in Formation of Regional Regulation No. 3 Of 2017 About organizing Entertainment Enterprises in Wonosobo}

- The lack of public interest in participating, is less the public about the importance of public participation in the establishment of regulations, when public participation is one important element in the formation of local regulations, public participation of the community is a right that can be implemented in the planning stages up in the discussion. Community involvement in the planning process, the planning policy formation, monitoring of development results and applicability of a policy, is something that encourages the success of the development of effective and efficient.

Manufacture Legislation formation and struggles as a field of interest, and as an institutionalization of social conflicts, considers that the Act also functions as a means of conflict resolution. Thus, regulatory legislation reflects the atmosphere of conflict between the power and interests of the community. ${ }^{21}$

- The government is still not optimal or DPDRD accommodate the aspirations of the community

According to Muhammad Rifai as citizens whose house is about 500 meters from where her karaoke entertainment at the meeting related discussions polls Number of local regulations. 3 Of 2017 About the organizers effort not only as participants of the meeting heard the advice or opinion. According to the author of this sort of thing is very detrimental to the community because the community around entertainment areas directly affected by the negative of entertainment venues ${ }^{22}$

This is contrary to the democratic values that exist in Indonesia, according to Miriam Budiardjo characteristic feature of democracy is: ${ }^{23}$

- constitutional protection

- Judiciary independent and impartial

- Free elections

- Freedom of expression

- freedom of association

- Their civic education

\footnotetext{
${ }^{20}$ Interview with Viandari Tia the head of the employers' Karaoke association of Wonosobo district February 16, 2019

${ }^{21}$ Satjipto Raharjo. 1998. Op.cit.

${ }^{22}$ Interview with Muhammad Rifai Wonosobo Citizen February 17, 2019

${ }^{23}$ Ibid.
} 
- Policies set on the basis of political will of the majority

The solution can be achieved by optimizing the participation of board members of public

- Improving the public interest by providing information about the importance of public participation in order to advance in the area, with their public participation then development will walk up. ${ }^{24}$

- Accommodate all the aspirations of all people with direct plunge into karaoke entertainment locations in Wonosobo for the right target for this regulation regarding the entertainment business. ${ }^{25}$

The process of community aspiration is twofold aspiration of society by the government and by the parliament aspiration by the government through the planning process and absorption by the DPRD directly and indirectly. ${ }^{26}$

\section{Closing}

\subsection{Conclusion}

- In the establishment of Regional Regulation No. 3 of 2017 on the Implementation of Enterprise Entertainment Wonosobo District and Government of Wonosobso District has involved public participation, but not quite up to it can be seen from the lack of community participate of impact of these regulations.

- Constraints in the Establishment of a lack of community interest in participating and the lack of government in accommodating society aspiration.

\subsection{Suggestion}

In the formation of local regulations should involve various stakeholders and not only among Islamic organizations but must involve the public widely especially the direct impact of their regulations.

\section{Bibliography}

[1] Satjipto Raharjo. 1998. "Mencari Model Ideal Penyusunan UU Yang Demokrasi (Kajian Sosiologis)". This paper explained in national seminar in case to search ideal model to make Law which democracy abnd Congress sociological law association of Indonesia, Semarang.

[2] Praptanugraha, 2008, Partisipasi Masyarakat Dalam Pembentukan Peraturan Daerah, Jurnal Hukum No. 3 VOL. 15 Juli 2008: 459 - 473, Fakultas Hukum Universitas Islam Indonesia

\footnotetext{
${ }^{24}$ Interview with Tofek. Op.cit

${ }^{25}$ Interview with Miswant, Op.cit.

${ }^{26}$ Ibid.
} 
[3] Nurdin H. kistanto,dkk, Sejarah wonosobo, Pemerintah Daerah Kabupaten WonosObo 2008), Wonosobo

[4] Roni Hanitijo Soemitro, 1990, Metodologi Penelitian Hukum dan Jurimeti, Ghalia Indonesia, Jakarta

[5] Act No. 12 Of 2011 on the Establishment Regulation Legislation

[6] Regional Regulation Number. 3 Of 2017 on the Implementation of Enterprise Entertainment in Wonosobo 